\title{
EVALUATION OF NATURAL GAS STRATEGIES OF TURKEY IN EAST MEDITERRANEAN REGION: A STRENGTHS-WEAKNESSES-OPPORTUNITIES-THREATS AND ANALYTIC NETWORK PROCESS APPROACH
}

\author{
Tolga GENÇ${ }^{1}$, Mehmet KABAK ${ }^{2}$, Eren ÖZCEYLAN ${ }^{3}$, Cihan ÇETINKAYA ${ }^{4^{*}}$ \\ ${ }^{1}$ Atatürk Faculty of Education, Near East University, 99138 Nicosia, Cyprus \\ ${ }^{2}$ Department of Industrial Engineering, Gazi University, 06570 Ankara, Turkey \\ ${ }^{3}$ Department of Industrial Engineering, Gaziantep University, 27310 Gaziantep, Turkey \\ ${ }^{4}$ Department of Management Information Systems, Adana Science and Technology University, \\ 01250 Adana, Turkey
}

Received 27 October 2015; accepted 23 October 2016

\begin{abstract}
Demand for natural gas has severely challenged the world supply among other types of energy sources such as coal, geothermal, nuclear and etc. Natural gas is the most important form of energy because it is clean, abundant, reliable and versatile. Due to the limited and transportable characterizes of natural gas, sharing pipelines for natural gas with other nations can either bring peace and stability or create chaos. To avoid insoluble strategies, it is very explicit to decide scientifically for these kinds of global issues. To do so, a SWOT (Strengths, Weaknesses, Opportunities and Threats) - ANP (Analytic Network Process) integrated approach is presented to evaluate natural gas policies for Turkey in terms of East Mediterranean Region. In the first step, the appropriate strategies, SO (strengths-opportunities), ST (strengths-threats), WO (weaknesses-opportunities) and WT (weaknesses-threats) are determined via SWOT analysis including four criteria, 20 sub-criteria and seven strategies. Due to inability of SWOT analysis to prioritize the criteria and rank the strategies, ANP approach which also considers the dependency between criteria is applied in the second step. Finally, the proposed SWOT-ANP approach is compared with other multi criteria decision making (MCDM) techniques to represent the effectiveness and applicability of the model.
\end{abstract}

Keywords: natural gas, strategic policy, evaluation, ANP, SWOT.

JEL Classification: C63, D81, M00, P48.

\section{Introduction}

Energy affects the quality of our lives significantly. Nowadays, we are addicted to continuous supply of energy for living and working. It is a leading actor in all sectors of modern economies. Energy demand in the world is increasing rapidly. Demand for energy in the world increased from 8769 million tons of oil equivalent (Mtoe) in 1990 to 13240 Mtoe in 2012 (Table 1).

*Corresponding author. E-mail: cihancetinkaya@gantep.edu.tr 
Table 1. World primary energy demand by fuel (Mtoe) (WEO 2014)

\begin{tabular}{|l|c|c|c|c|c|c|c|c|}
\hline \multicolumn{1}{|c|}{ Energy Demand } & 1990 & 2000 & 2012 & 2020 & 2025 & 2030 & 2035 & $2012-2035^{*}$ \\
\hline Oil & 3231 & 3663 & 4158 & 4469 & 4545 & 4600 & 4666 & $0.5 \%$ \\
\hline Gas & 1668 & 2072 & 2869 & 3234 & 3537 & 3824 & 4127 & $1.6 \%$ \\
\hline Coal & 2230 & 2357 & 3796 & 4137 & 4238 & 4309 & 4398 & $0.6 \%$ \\
\hline Nuclear & 526 & 676 & 642 & 869 & 969 & 1051 & 1118 & $2.4 \%$ \\
\hline Hydropower & 184 & 225 & 313 & 391 & 430 & 466 & 501 & $2.1 \%$ \\
\hline Biomass and Waste & 893 & 1016 & 1318 & 1488 & 1598 & 1718 & 1848 & $1.5 \%$ \\
\hline Other Renewables & 36 & 60 & 142 & 311 & 432 & 566 & 717 & $7.3 \%$ \\
\hline Total (Mtoe) & 8769 & 10070 & 13240 & 14899 & 15749 & 16534 & 17376 & $1.2 \%$ \\
\hline
\end{tabular}

Note: ${ }^{\star}$ Average annual growth rate.

Countries which are close to the East Mediterranean Region including Cyprus, Greece, Lebanon, Syria, Israel, State of Palestine, Turkey, Egypt, Jordan, and Libya and some countries from Europe (Italy, Albania and etc.) will inevitably be affected from stability or instability of the region. It is the fact that energy transportation is as important as having energy sources. Sharing energy sources can either bring peace and stability or create chaos for the region. To achieve a sustainable energy policy, countries in this region and neighboring countries should implement peaceful strategies for energy. Natural gas is the most important form of energy because it is clean, abundant, reliable and versatile. In recent years, gas supply has rose when compared to other energy sources in the region. Figure 1 shows the total primary energy supply in East Mediterranean Region, and gas energy is increasing from $46 \%$ to $54 \%$ from 2009 to 2020 . The gas inevitably will be transferred from East Mediterranean Region to Europe, which is one of the biggest energy markets. The total magnitude of natural gas resources in the East Mediterranean is difficult to assess. The U.S. Geological Survey has estimated resources in the region at 3,500 billion cubic meters $(\mathrm{bcm})$. This could guarantee gas supplies for the region for 50-100 years. However these estimates are not confirmed and it is not yet clear if the production of these quantities from great depths at sea will always be economically viable (Koehler 2012). Still The Eastern Mediterranean catchment basin has emerged as a natural gas producing region recently. Spurred by discoveries and production offshore of Egypt and Israel, exploration has intensified in the basin, and additional natural gas and oil discoveries are likely during the current decade (Shaffer 2012). The Eastern Mediterranean region contains eight significant basins for gas sources (Cyprus Basin, Eratosthenes High, Latakia Basin, Levant Basin, Judea Basin, Nile Delta Basin, Western Arabian province and Zagros province). As shown in Figure 2, Levant Basin has high importance and capacity. In the region, important natural gas fields that were discovered in the past decade that belongs to the Levant Basin. They are mostly in Israel's territorial waters, but there are some significant discoveries in Cyprus and the Palestinian Territories too (AEO 2013).

Currently, the new discoveries of Israel and Cyprus won't be a game changer for European and Asian markets. However, if some additional volumes are discovered then authorization is given for export, European Union and third-country markets may also benefit. In any 

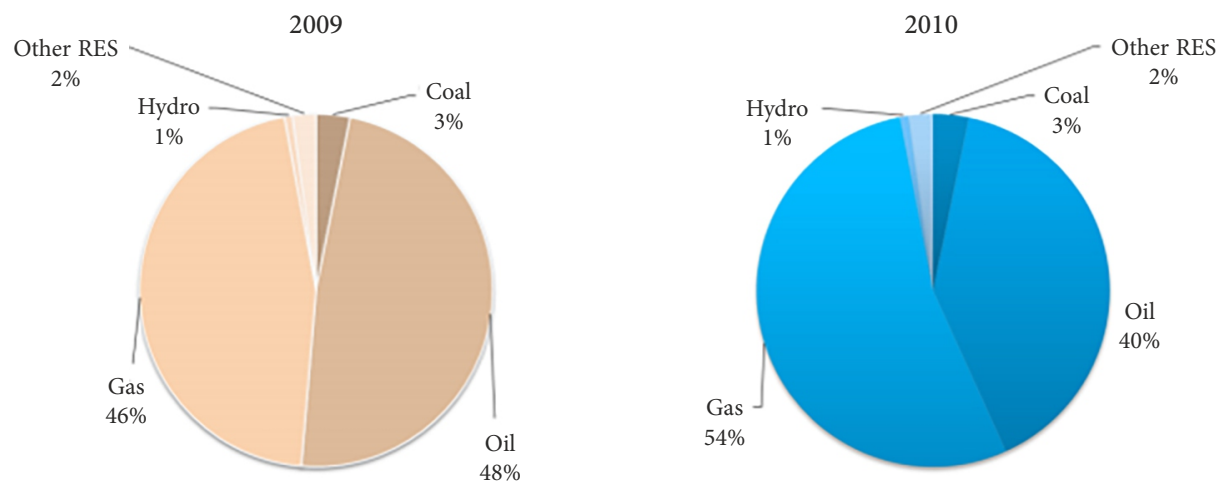

Fig. 1. Total primary energy supply in East Mediterranean Region (OME 2011)

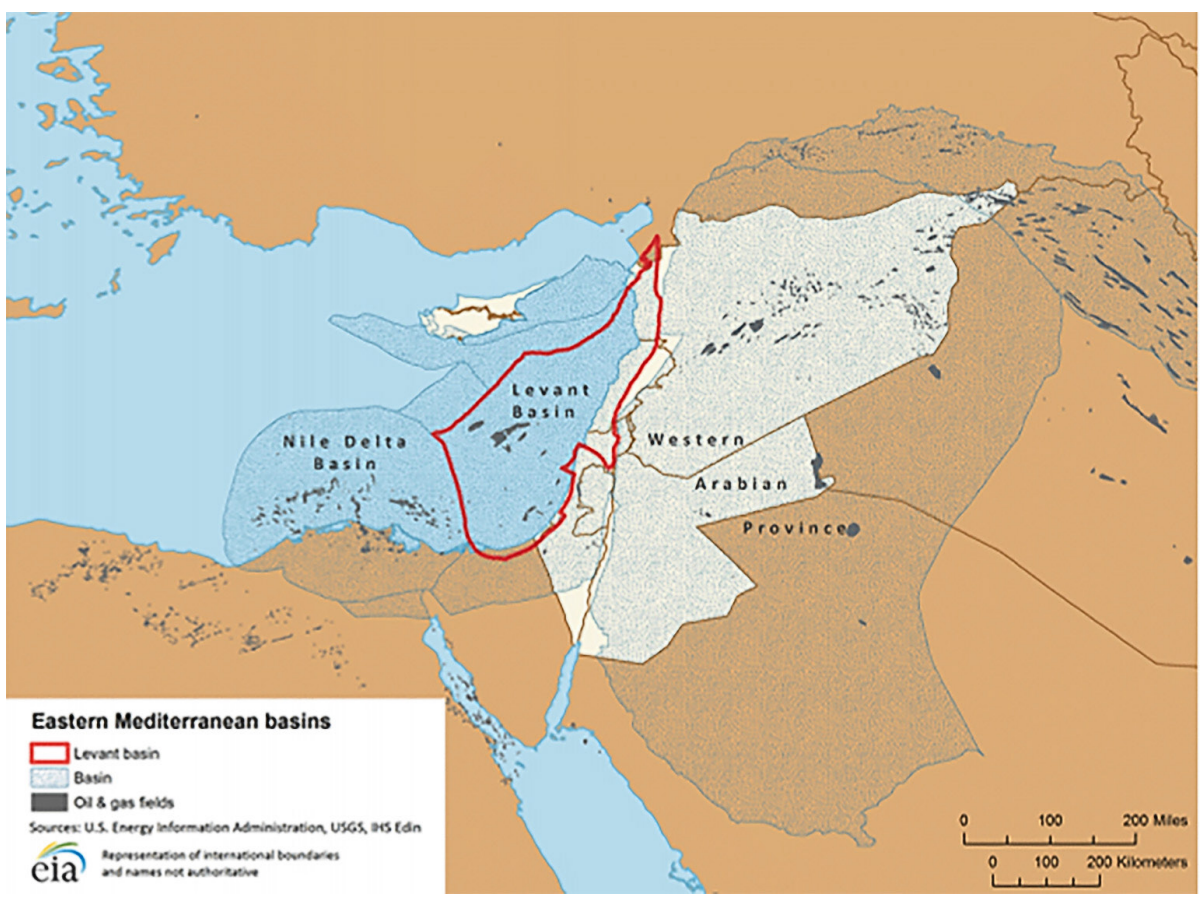

Fig. 2. Levant Basin in East Mediterranean Region (AEO 2013)

case, the new discoveries are important for the region and it will change the usage of energy (Shaffer 2012). The increasing importance of the region will effect political situation due to sharing of sources. The conflicts and disputes in a region are forcing the countries to implement suitable strategic energy policies based on scientific methods. If the strategic decisions do not have scientific basis, they may change according to people who are in charge of a country. Also energy policies have different instruments to attach. The context is related not 
only with the energy supply/demand, but also political, environmental, administrative, legal and market issues. The concern about security and external source safety is also a major issue. Strategies should be developed by considering every detail. Governmental and public concern has focused on the risks associated with dependence on external sources, political uncertainty in external supplier and transit states, and the potential for disruptions to energy supplies (ECA 2015). The security of energy is gaining extra importance when we focus on the Eastern Mediterranean Region. For that reason, we will formulate the strategies considering all the possible effects.

Significant amount of researches have been proposed to find suitable solutions or strategies for energy policies in recent years. For those strategies, researchers need applicable mathematical approaches and convenient specialist remarks because increasing complexity of energy supply and traditional form of planning processes would make it difficult for the decision makers to decide in appropriate ways. In the analysis process, to determine the definition of problem and to formulate the strategy for the solutions is a requisite determinant. SWOT analysis is important for systematic analysis of both internal / external factors thus becoming an important decision making tool. It is a useful model for any systems that try to identify strengths, weaknesses, opportunities and threats. By doing so, SWOT analysis tries to analyze the internal situation and external conditions; as a result decision makers design their strategies accordingly (Chaghooshi et al. 2011). SWOT analysis mainly deals with strategic planning process however its area of interest is not limited with it. Strategic planners and academicians use SWOT analysis in various fields, such as strategies for enterprises (Houben et al. 1999; Chang, Huang 2006; Yüksel, Dağdeviren 2007; Hashemi et al. 2011; Jeyaraj et al. 2012), city planning (Vanek et al. 2012), regional planning (Karppi et al. 2001), health care (Harrison 2010). To get the full advantage of SWOT, it is important to use the tool correctly. The analysis should provide decision makers with related information to make the strategic decisions. It means that, the lists of strengths, weaknesses, opportunities and threats are not helpful themselves. It helps when the potential implications of this information for the organization are conducted that the planners can get significant analysis (Chang, Huang 2006). Even applied properly, SWOT analysis does not provide an analytical means to determine the importance of the identified factors or the ability to assess decision alternatives according to these factors (Yüksel, Dağdeviren 2007).

After formulating the strategies for the strategic planning process, literature presents various mathematical approaches to find a solution for the decision makers. The Analytic Network Process seems one of the featured methods among them. Considering all the disputes, the sustainable energy strategies are vital for the countries in the region and neighboring countries. To advise a scientific strategy for Turkey, a hybrid MCDM approach for reasonable decisions is proposed in this paper. To do so, a SWOT-ANP integrated approach is presented to evaluate natural gas policies for the East Mediterranean Region in this study. In the first step, the appropriate strategies, SO (strengths-opportunities), ST (strengths-threats), WO (weaknesses-opportunities) and WT (weaknesses-threats) are determined via SWOT analysis including four criteria, 20 sub-criteria and seven strategies. Due to inability of SWOT analysis to prioritize the criteria and rank the strategies, ANP approach which also considers the dependency between criteria is applied in the second step. Finally, the proposed SWOT-ANP 
approach is compared with other MCDM techniques to represent the effectiveness and applicability of the model.

Our paper is formed as follows; the related literature including SWOT and ANP methods will be explained in Section 2. SWOT analysis, ANP approach and proposed model which combines SWOT and ANP methodologies will be presented briefly in Section 3. Application of proposed methodology to natural gas strategy problem will be provided in Section 4. In the last section, the findings will be discussed and conclusion will be stated.

\section{Literature review}

The researchers who integrate MCDM techniques and SWOT analysis are common in literature. SWOT method provides a frame related to the decision situation, but it is unable to rank neither the strategies nor the factors. But the dependency between factors affects the priority of strategies. Thus, the MCDM techniques assist in doing SWOT analysis more analytically and thoroughly so that those strategic decision alternatives can be prioritized. Therefore, Analytical Hierarchy Process (AHP) and Analytical Network Process (ANP) are usually applied to examine whether the dependency among the factors changes the priorities of strategies (Yüksel, Dağdeviren 2007; Zheng, Liu 2013; Zhou, Chen 2014). Besides AHP and ANP approaches, VIKOR (Azimi et al. 2011b), DELPHI (Tavana et al. 2012) and TOPSIS (Arabzad et al. 2015) methods are also used within SWOT analysis in literature. The merits and demerits of various MCDM methods have been described in Table 2.

Azimi et al. (2011a, 2011b) surveyed the Iranian mining sector with different methodologies and from different points of view in two studies. They prioritized the strategies and alternatives by TOPSIS and VIKOR in addition to SWOT analysis. Babaesmailli et al. (2012) examined a tile manufacturing firm as a case and described the dependency among factors and sub-factors effecting the decisions. Sevkli et al. (2012) examined the strategic management of an airline industry in Turkey while Tavana et al. (2012) examined the strategies of an Oil Company focusing on Caspian Sea basin. Zhou and Chen (2014) prioritized strategies for grassland management in China. As recent studies; Lee (2015) surveyed location selection for secondhand tier city in China, Groselj and Stirn (2015) and Reinsberger et al. (2015) examined environmental management problems for Slovenia and Austria.

To improve the efficiency of SWOT analysis, some extensions have been applied to SWOT in recent years. A'WOT method that is one of them is an integrated method of AHP with SWOT analysis (Kajanus et al. 2004). The aim of applying the hybrid method is to improve the quantitative basis of strategic planning processes. After applying the A'WOT method, decision-makers have information at their disposal about how alternative strategies are congruent with internal and external factors. Since MCDM problems and techniques are very common in literature, we will focus only on the techniques which are used together by SWOT. The proposed technique in this paper is SWOT-ANP and as can be seen below, Table 3 gives a summary of the researches practically and briefly about this technique. As it is seen from Table 3, SWOT-ANP technique is used in prioritizing alternatives of strategic decisions. But, to the best of our knowledge, it has not been used in energy strategy decision making in literature yet. Thus the paper mainly focuses on SWOT-ANP analysis about natural gas strategies of Turkey. 
Table 2. MCDM methods with its merits and demerits (Aruldoss et al. 2013; Gavade 2014)

\begin{tabular}{|c|c|c|c|}
\hline Methods & Description & Advantages & Disadvantages \\
\hline AHP & $\begin{array}{l}\text { It builds the decision } \\
\text { problem from arrangement } \\
\text { of different goals, criteria } \\
\text { and alternatives and pair } \\
\text { wise comparison of the } \\
\text { criteria to obtain the best } \\
\text { alternative. }\end{array}$ & $\begin{array}{l}\text { (i) Flexible, intuitive and } \\
\text { checks inconsistencies; } \\
\text { (ii) Since problem is } \\
\text { constructed into a } \\
\text { hierarchical structure, } \\
\text { the importance of each } \\
\text { element becomes clear; } \\
\text { (iii) No bias in decision } \\
\text { making. }\end{array}$ & $\begin{array}{l}\text { (i) Irregularities in } \\
\text { ranking; (ii) Additive } \\
\text { aggregation is used. So } \\
\text { important information } \\
\text { may be lost; (iii) More } \\
\text { number of pair wise } \\
\text { comparisons are needed. }\end{array}$ \\
\hline ANP & $\begin{array}{l}\text { It is a generalization of the } \\
\text { AHP, by considering the } \\
\text { dependence between the } \\
\text { elements of the hierarchy. } \\
\text { Therefore, It is represented } \\
\text { by a network, rather than a } \\
\text { hierarchy. }\end{array}$ & $\begin{array}{l}\text { (i) Independence among } \\
\text { elements is not required; } \\
\text { (ii) Prediction is accurate } \\
\text { because priorities are } \\
\text { improved by feedback. }\end{array}$ & $\begin{array}{l}\text { (i) Time consuming; } \\
\text { (ii) Uncertainty - not } \\
\text { supported; (iii) Hard } \\
\text { to convince decision } \\
\text { making. }\end{array}$ \\
\hline TOPSIS & $\begin{array}{l}\text { It is a method of } \\
\text { compensatory aggregation } \\
\text { that compares a set of } \\
\text { alternatives by identifying } \\
\text { weights for each criterion, } \\
\text { normalizing scores for each } \\
\text { criterion and calculating the } \\
\text { geometric distance between } \\
\text { each alternative and the ideal } \\
\text { alternative, which is the best } \\
\text { score in each criterion. }\end{array}$ & $\begin{array}{l}\text { (i) Easy decision making } \\
\text { using both negative and } \\
\text { positive criteria; (ii) } \\
\text { Number of criteria can } \\
\text { be applied during the } \\
\text { decision process; (iii) } \\
\text { Simpler and faster than } \\
\text { AHP and ANP. }\end{array}$ & $\begin{array}{l}\text { (i) Operation of } \\
\text { normalized decision } \\
\text { matrix in which the } \\
\text { normalized scale for } \\
\text { each criterion is usually } \\
\text { derived a narrow gap } \\
\text { among the performed } \\
\text { measures. }\end{array}$ \\
\hline VIKOR & $\begin{array}{l}\text { It was developed to solve } \\
\text { MCDM problems with } \\
\text { conflicting and non- } \\
\text { commensurable (different } \\
\text { units) criteria, assuming that } \\
\text { compromising is acceptable } \\
\text { for conflict resolution, the } \\
\text { decision maker wants a } \\
\text { solution that is the closest to } \\
\text { the ideal, and the alternatives } \\
\text { are evaluated according to all } \\
\text { established criteria. }\end{array}$ & $\begin{array}{l}\text { (i) Proposing a } \\
\text { compromise solution } \\
\text { with an advantage rate; } \\
\text { (ii) avoiding the pair- } \\
\text { wise comparisons. }\end{array}$ & $\begin{array}{l}\text { (i) The performance } \\
\text { rating is quantified as } \\
\text { crisp values. }\end{array}$ \\
\hline ELECTRE & $\begin{array}{l}\text { It is used to select the best } \\
\text { choice with maximum } \\
\text { advantage and least conflict } \\
\text { in the function of various } \\
\text { criteria. }\end{array}$ & $\begin{array}{l}\text { (i) Outranking is used; } \\
\text { (ii) Accepts qualitative } \\
\text { and quantitative criteria. }\end{array}$ & $\begin{array}{l}\text { (i) Time consuming; (ii) } \\
\text { Difficult to understand } \\
\text { because of the principles } \\
\text { used in determining } \\
\text { the concordance and } \\
\text { discordance matrices. }\end{array}$ \\
\hline PROMETHEE & $\begin{array}{l}\text { It is an outranking method } \\
\text { for a finite set of alternative } \\
\text { actions to be ranked and } \\
\text { selected among criteria, } \\
\text { which are often conflicting. }\end{array}$ & $\begin{array}{l}\text { (i) It can simultaneously } \\
\text { deal with qualitative and } \\
\text { quantitative criteria; (ii) } \\
\text { Criteria scores can be } \\
\text { expressed in their own } \\
\text { units; (iii) It needs much } \\
\text { less inputs. }\end{array}$ & $\begin{array}{l}\text { (i) It suffers from the } \\
\text { rank reversal problem } \\
\text { when a new alternative } \\
\text { is introduced; (ii) It } \\
\text { does not provide the } \\
\text { possibility to really } \\
\text { structure a decision } \\
\text { problem. }\end{array}$ \\
\hline
\end{tabular}


Table 3. MCDM techniques combined with SWOT in literature

\begin{tabular}{|c|c|c|c|}
\hline Authors & Methods & Problem & Solution \\
\hline $\begin{array}{l}\text { Yüksel, } \\
\text { Dağdeviren } \\
(2007)\end{array}$ & SWOT, ANP & $\begin{array}{l}\text { Evaluating of strategies for } \\
\text { a textile company. }\end{array}$ & $\begin{array}{l}\text { Criteria for determining the best } \\
\text { strategy are prioritized by ANP. }\end{array}$ \\
\hline $\begin{array}{l}\text { Azimi et al. } \\
\text { (2011a) }\end{array}$ & $\begin{array}{l}\text { SWOT, ANP, } \\
\text { TOPSIS }\end{array}$ & $\begin{array}{l}\text { Ranking the strategies of } \\
\text { mining sector in Iran. }\end{array}$ & $\begin{array}{l}\text { ANP is applied in order to obtain the } \\
\text { weight of SWOT factors, the strategies } \\
\text { are ranked through TOPSIS. }\end{array}$ \\
\hline $\begin{array}{l}\text { Azimi et al. } \\
\text { (2011b) }\end{array}$ & SWOT, VIKOR & $\begin{array}{l}\text { Evaluating the strategies of } \\
\text { the Iranian mining sector } \\
\text { using an integrated model. }\end{array}$ & $\begin{array}{l}\text { Six strategy alternatives are prioritized } \\
\text { and ranked by VIKOR. }\end{array}$ \\
\hline $\begin{array}{l}\text { Babaesmailli } \\
\text { et al. }(2012)\end{array}$ & $\begin{array}{l}\text { SWOT, FUZZY } \\
\text { ANP }\end{array}$ & $\begin{array}{l}\text { Prioritizing strategies for } \\
\text { tile manufacturing firm. }\end{array}$ & $\begin{array}{l}\text { Dependency among factors and sub- } \\
\text { factors, are shown by ANP. }\end{array}$ \\
\hline $\begin{array}{l}\text { Sevkli et al. } \\
(2012)\end{array}$ & $\begin{array}{l}\text { SWOT, FUZZY } \\
\text { ANP }\end{array}$ & $\begin{array}{l}\text { Determining the ranking } \\
\text { of the factors in SWOT } \\
\text { analysis for airline } \\
\text { industry. }\end{array}$ & $\begin{array}{l}\text { SWOT with fuzzy ANP methodology } \\
\text { was implemented and tested for the } \\
\text { Turkish airline industry for strategic } \\
\text { management. }\end{array}$ \\
\hline $\begin{array}{l}\text { Tavana et al. } \\
(2012)\end{array}$ & $\begin{array}{l}\text { SWOT, } \\
\text { DELPHI }\end{array}$ & $\begin{array}{l}\text { Oil and gas pipeline } \\
\text { strategic planning in } \\
\text { Caspian Sea basin. }\end{array}$ & $\begin{array}{l}\text { Horizon Oil Company is assisted in } \\
\text { evaluating five export routes by Delphi. }\end{array}$ \\
\hline Bas (2013) & $\begin{array}{l}\text { SWOT, FUZZY } \\
\text { TOPSIS, AHP }\end{array}$ & $\begin{array}{l}\text { Analysis of electricity } \\
\text { supply chain in Turkey. }\end{array}$ & $\begin{array}{l}\text { SWOT with fuzzy TOPSIS } \\
\text { methodology combined with AHP } \\
\text { is proposed to prioritize the defined } \\
\text { SWOT factors for formulating a } \\
\text { strategy plan with priorities }\end{array}$ \\
\hline $\begin{array}{l}\text { Zheng, Liu } \\
(2013)\end{array}$ & SWOT, ANP & $\begin{array}{l}\text { Evaluating multifunctional } \\
\text { agriculture in China. }\end{array}$ & $\begin{array}{l}\text { The multi functionalities between rural } \\
\text { areas are compared by ANP. }\end{array}$ \\
\hline $\begin{array}{l}\text { Tavana et al. } \\
(2013)\end{array}$ & $\begin{array}{l}\text { SWOT, } \\
\text { DELPHI, } \\
\text { PROMETHEE }\end{array}$ & $\begin{array}{l}\text { Oil and gas pipeline } \\
\text { planning in the Caspian } \\
\text { Sea basin. }\end{array}$ & $\begin{array}{l}\text { SWOT with Delphi method is used to } \\
\text { capture the decision makers' beliefs. } \\
\text { PROMETHEE is used to integrate } \\
\text { these beliefs with subjective judgments. }\end{array}$ \\
\hline $\begin{array}{l}\text { Shahabi } \\
\text { et al. }(2014)\end{array}$ & SWOT, ANP & $\begin{array}{l}\text { Analysis and prioritizing } \\
\text { the Iran's steel scrap } \\
\text { industry strategies. }\end{array}$ & $\begin{array}{l}\text { Dependency among factors and sub- } \\
\text { factors, are shown by ANP. }\end{array}$ \\
\hline $\begin{array}{l}\text { Zhou, Chen } \\
\text { (2014) }\end{array}$ & SWOT, AHP & $\begin{array}{l}\text { Grassland management in } \\
\text { China. }\end{array}$ & $\begin{array}{l}\text { A strategy for grassland management } \\
\text { is offered after prioritizing strategies } \\
\text { by ANP. }\end{array}$ \\
\hline Lee (2015) & $\begin{array}{l}\text { SWOT, FUZZY } \\
\text { ANP, GSM }\end{array}$ & $\begin{array}{l}\text { Location selection for a } \\
\text { second tier city in China. }\end{array}$ & $\begin{array}{l}\text { Cities are selected as the best } \\
\text { alternatives for second tier city } \\
\text { locations by a hybrid technique. }\end{array}$ \\
\hline $\begin{array}{l}\text { Groselj, } \\
\text { Stirn (2015) }\end{array}$ & SWOT, ANP & $\begin{array}{l}\text { Environmental } \\
\text { management problem of } \\
\text { Pohorje, Slovenia. }\end{array}$ & $\begin{array}{l}\text { Identification of the alternatives is done } \\
\text { by AHP. }\end{array}$ \\
\hline $\begin{array}{l}\text { Reinsberger } \\
\text { et al. }(2015)\end{array}$ & SWOT, AHP & $\begin{array}{l}\text { Challenges related to } \\
\text { photovoltaics in Austria } \\
\text { about energy transition. }\end{array}$ & $\begin{array}{l}\text { SWOT factors about energy transition } \\
\text { are evaluated by AHP. }\end{array}$ \\
\hline $\begin{array}{l}\text { Arabzad } \\
\text { et al. }(2015)\end{array}$ & $\begin{array}{l}\text { SWOT, FUZZY } \\
\text { TOPSIS }\end{array}$ & $\begin{array}{l}\text { Supplier selection and } \\
\text { order allocation problem. }\end{array}$ & $\begin{array}{l}\text { Supplier selection criteria are } \\
\text { determined by fuzzy TOPSIS from } \\
\text { strategic point of view. }\end{array}$ \\
\hline
\end{tabular}




\section{The proposed research framework}

This section presents brief information on the SWOT analysis, followed by the same for the ANP approach. Finally, the proposed SWOT-ANP approach is given briefly.

\subsection{Strengths-weaknesses-opportunities-threats analysis}

SWOT analysis is commonly used as a way to analyze an organization's internal and external environments and this makes it an important support tool for decision making (Kangas et al. 2003). It is widely used for analyzing internal and external environments in order to attain a systematic understanding of a strategic management situation (Wheelen, Hunger 1995). It encourages strategists to bring up a strategy that can best fit with the situation. The philosophy of SWOT is that; the strategies of an organization should match the environmental threats / opportunities and with the organization's weaknesses and strengths. It tries to establish a strategic fit between an organization's internal strengths and weaknesses and the opportunities and threats posed by its external environment ( $\mathrm{Lu} 2010)$. By identifying its strengths, weaknesses, opportunities, and threats, the countries can build strategies upon its strengths, eliminate its weaknesses, and exploit its opportunities or use them to counter the threats. Developing a SWOT matrix and identifying the elements contribute to see the main internal and external powers of the systems. Elaborate analysis of the above mentioned factors would put forth the strategies of the countries in any matter.

The SWOT matrix presents the linkage between the country's strengths and weaknesses (internal factors) and threats and opportunities (external factors) in the strategic planning. Thus it provides a framework for identifying strategies. The most challenging part of generating a SWOT matrix is matching the key internal and external factors. SWOT matrix helps decision makers to develop four types of strategies respectively as illustrated in Table 4, namely SO (strengths-opportunities) strategies, WO (weaknesses-opportunities) strategies, ST (strengths-threats) strategies and WT (weaknesses-threats) strategies.

SO strategies use a country's internal strengths to benefit from external opportunities. WO strategies try to take advantage of external opportunities and try to improve internal weaknesses. ST strategies use a country's strengths to avoid or reduce the impact of external threats. WT strategies try to reduce the internal weaknesses and avoid the environmental threats as a defending technique (Weihrich 1982). There are eight steps involved in constructing a SWOT matrix: (1) listing the key external opportunities, (2) listing the key external threats, (3) listing the key internal strengths, (4) listing the key internal weaknesses, (5) matching internal strengths with external opportunities and recording the resultant SO strategies, (6) matching internal weaknesses with external opportunities and recording the resultant WO strategies, (7) matching internal strengths with external threats and recording the resultant ST strategies and (8) matching internal weaknesses with external threats and recording the resultant WT strategies (David 2007). 
Table 4. A generic presentation of the SWOT matrix (Sevkli et al. 2012)

\begin{tabular}{|c|c|c|}
\hline Internal & STRENGTHS-S & WEAKNESSES-W \\
\hline Factors & 1. & 1. \\
\hline & & 2. \\
\hline & . List of Strengths & . List of Weaknesses \\
\hline External & & . \\
\hline Factors & $\mathrm{N}$ & $\mathrm{N}$ \\
\hline OPPORTUNITIES-O & SO STRATEGIES & WO STRATEGIES \\
\hline 1. & 1. & 1. \\
\hline 2. & 2. & 2. \\
\hline List of Opportunities & Use strengths to take advantage & Overcome weaknesses by taking \\
\hline . & or opportunities & . advantage or opportunities \\
\hline $\mathrm{N}$ & $\mathrm{N}$ & $\mathrm{N}$ \\
\hline THREATS-T & ST STRATEGIES & WT STRATEGIES \\
\hline 1. & 1. & 1. \\
\hline 2. & 2. & 2. \\
\hline . List of Threats & . Use strengths to avoid threats & $\begin{array}{l}\text { Minimize weaknesses } \\
\text { to avoid threats }\end{array}$ \\
\hline . & . & . \\
\hline $\mathrm{N}$ & $\mathrm{N}$ & $\mathrm{N}$ \\
\hline
\end{tabular}

\subsection{Analytic network process approach}

Many decision problems cannot be structured hierarchically because they involve the interaction and dependence of higher-level elements in a hierarchy on lower-level elements. Not only does the importance of the criteria determine the importance of the alternatives as in a hierarchy, but also the importance of the alternatives themselves determines the importance of the criteria (Saaty, Vargas 2006). AHP is an approach which is suitable for dealing with complex systems related to making a choice from among several alternatives. It provides a comparison of the considered options. This method was first presented by Saaty in 1980. It is based on the subdivision of the problem in a hierarchical form. It helps to organize the critical aspects of a problem into a hierarchical structure similar to a family tree. By reducing complex decisions to a series of simple comparisons and rankings, then synthesizing the results, AHP helps the analysts to give the best decision, and also it provides a clear rationale for the choices to be made. The objective of using AHP is to identify the preferred alternative and also determine a ranking of the alternatives when all the decision criteria are considered simultaneously (Saaty 1980).

Saaty (1994) introduced ANP, a new generation of MCDM theory, to replace the AHP. The ANP method is a general theory of relative measurement used to derive composite priority ratio scales from individual ratio scales that represent relative measurements of the influence of elements that interact with respect to control criteria. As mentioned by Saaty (2005), ANP model consists of two main parts, that are a network of interrelationships among each two nodes or clusters and a control network of criteria or sub-criteria that controls interactions based on interdependencies and feedback. Here, nodes are indica- 
tors of criteria for model construction, while clusters are groups of indicators for classifying criteria. In order to make a decision making process, a control hierarchy is generally employed to build an ANP model. The control hierarchy is a hierarchy of criteria and sub-criteria for which priorities are derived in the usual way with respect to the goal of a system being considered. The criteria are used to compare the clusters of an ANP model, while the sub-criteria are used to compare the nodes inside a cluster (Adam, Humphreys 2008). ANP approach that is based on the much stronger, absolute scales used to represent pairwise comparison judgments in the context of dominance with respect to a property shared by the homogeneous elements being compared (Saaty, Vargas 2006). The AHP allows for complex interrelationships among decision levels in a hierarchical structure (Saaty 1994). Many decision problems include interaction between criteria and alternatives or dependence of higher level elements in a hierarchy on lower level elements; therefore, they cannot be configured as a hierarchical decision problem. Although AHP allows a framework for uni-directional hierarchical relationships, the ANP is suitable for complex interrelationships among decision levels and alternatives (Saaty, Özdemir 2005). The AHP allows for complex interrelationships among decision levels and attributes (Saaty 1994). The ANP feedback approach replaces hierarchies (Fig. 3a) with networks (Fig. 3b) in which the relationships between levels cannot be easily represented as higher or lower, dominant or subordinate, direct or indirect (Saaty, Vargas 1998).

a)

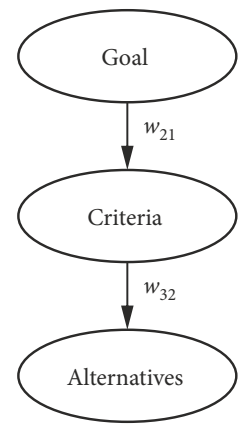

b)

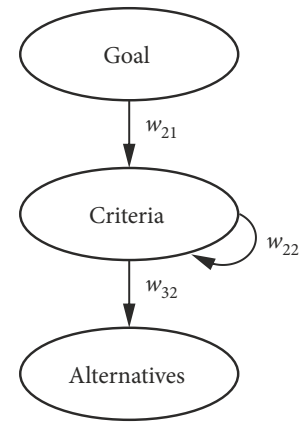

Fig. 3. Hierarchy and network: (a) hierarchy; (b) network (Yüksel, Dağdeviren 2007)

In ANP, the modelling process can be divided to three steps, that are described as follows:

\section{Step 1: The Pairwise Comparisons and Relative Weight Estimation.}

Before performing the pairwise comparisons, all criteria and clusters compared are linked to each other. The pairwise comparisons are made depending on the scale of ANP. In the pairwise comparison matrix, the score of $a_{i j}$ represents the relative importance of the component on row $(i)$ over the component on column $(j)$, The reciprocal value of the expression ( $1 /$ $a_{i j}$ ) is used when the component $j$ is more important than the component $i$. The comparison matrix $A$ is defined as: 


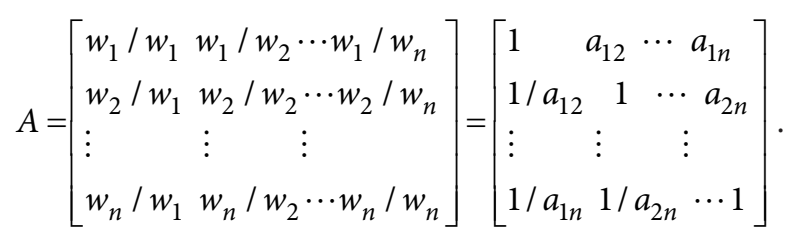

Then, a local priority vector (eigenvector) $w$ is computed as an estimate of the relative importance accompanied by the elements being compared by solving the equation (2).

$$
A w=\lambda_{\max } w
$$

where $\lambda_{\max }$ is the largest eigenvalue of matrix A.

Step 2: Formation of the Initial Supermatrix.

The Supermatrix representation of a network with three levels is given as follows (Fig. 3b):

$$
W=\begin{gathered}
G \\
\text { Goal }(\mathrm{G}) \\
\text { Criteria }(\mathrm{C}) \\
\text { Alternatives (A) }
\end{gathered}\left(\begin{array}{llll}
0 & 0 & 0 \\
W_{21} & W_{22} & 0 \\
0 & W_{32} & \mathrm{I}
\end{array}\right) .
$$

$W_{21}$ is a vector that represents the impact of the goal on the criteria, $W_{22}$ is a vector that represents impact of the interdependences among criteria, $W_{32}$ is also a vector that represents the impact of criteria on each of alternatives, and $I$ is the identity matrix. Any zero value in the super-matrix can be replaced by a matrix if there is an interrelationship of elements within a cluster or between the clusters.

Step 3: Formation of the Weighted Supermatrix.

An eigenvector is obtained from the pairwise comparison matrix of the row clusters with respect to the column cluster, which in turn yields an eigenvector for each column cluster. The first entry of the respective eigenvector for each column cluster is multiplied by all the elements in the first cluster of that column, the second by all the elements in the second cluster of that column and so on. In this way, the cluster in each column of the supermatrix is weighted, and the result, known as the weighted supermatrix is stochastic.

\subsection{Proposed model}

Purpose of model is to identify Turkey's natural gas policies and evaluate them regarding to East Mediterranean Region based on Analytic Network Process and SWOT Analysis for conducting integrated impact assessment. To do so, the proposed model is applied in three basic stages. In the first stage, the efficient strategic factors (Strengths, Weaknesses, Opportunities and Threats) and the appropriated strategies, SO, ST, WO and WT are determined via the SWOT analysis. SWOT factors as criteria, SWOT sub-factors as the sub-criteria and the strategies as alternatives are placed in downward order of hierarchy structure. A study team was employed to identify the internal and environmental strategic factors to fulfill the strategic planning analysis. Weights of criteria and sub-criteria are prioritized via ANP in 
the second stage. Linguistic terms shown in Table 5 are used to evaluate criteria weights. At last stage, final priorities of strategies are obtained in ANP analysis.

Schematic diagram of the proposed model for distance education websites evaluation is shown at Figure 4.

According to Figure 4, the goal - natural gas strategies in East Mediterranean Region - is determined firstly, and then the team of experts is made. After the determination of strengths, weaknesses, opportunities and threats of the natural gas policies, SWOT matrix is built. By obtaining the pairwise comparisons from experts, weights are calculated via ANP. Finally, alternative strategies are evaluated and ranked.

Table 5. 1-9 scale used for criteria comparisons (Saaty 1996)

\begin{tabular}{|l|l|l|}
\hline \multicolumn{1}{|c|}{$\begin{array}{c}\text { Intensity of } \\
\text { importance }\end{array}$} & \multicolumn{1}{|c|}{ Definition } & \multicolumn{1}{c|}{ Explanation } \\
\hline 1 & Equal importance & Two activities contribute equally to the objective \\
\hline 3 & $\begin{array}{l}\text { Moderate } \\
\text { importance }\end{array}$ & $\begin{array}{l}\text { Experience and judgment slightly favor one over } \\
\text { another }\end{array}$ \\
\hline 5 & Strong importance & $\begin{array}{l}\text { Experience and judgment strongly favor one } \\
\text { over another }\end{array}$ \\
\hline 7 & $\begin{array}{l}\text { Very strong } \\
\text { importance }\end{array}$ & $\begin{array}{l}\text { Activity is strongly favored and its dominance } \\
\text { is demonstrated in practice }\end{array}$ \\
\hline 9 & $\begin{array}{l}\text { Absolute } \\
\text { importance }\end{array}$ & $\begin{array}{l}\text { Importance of one over another affirmed on the } \\
\text { highest possible order }\end{array}$ \\
\hline $2,4,6,8$ & Intermediate values & $\begin{array}{l}\text { Used to represent compromise between the } \\
\text { priorities listed above }\end{array}$ \\
\hline $\begin{array}{l}\text { Reciprocal of above } \\
\text { non-zero numbers }\end{array}$ & $\begin{array}{l}\text { if activity } i \text { has one of the above non-zero numbers assigned to it when compared } \\
\text { with activity } j, \text { then } j \text { has the reciprocal value when compared with } i\end{array}$ \\
\hline
\end{tabular}

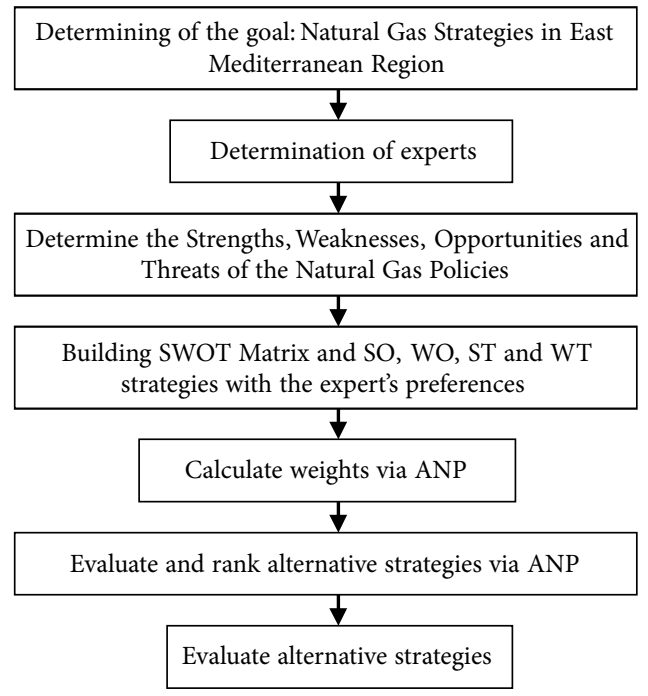

Fig. 4. An overview of the proposed model 


\section{Application of the proposed model}

This section describes the application of proposed SWOT-ANP approach on evaluating natural gas strategies in East Mediterranean Region. The Eastern Mediterranean denotes the countries geographically to the east of the Mediterranean Sea. The countries of the Eastern Mediterranean include: Cyprus, Greece, Lebanon, Syria, Israel, State of Palestine, Turkey, Egypt, Jordan, and Libya. Hierarchy structure of problem is defined to select best natural gas strategy/policy of Eastern Mediterranean region as goal placed at the top of hierarchy. Bottom of the hierarchy structure is constructed by a study team. Two experts from Ministry of Energy and Natural Resources and four authors have participated to the study. In SWOT analysis, 20 sub-criteria are determined by experts and then the main natural gas strategies based on interactions between SWOT sub-factors and expert's ideas were grouped into 7 major strategies. Obtained SWOT matrix is shown in Table 6. To give a detailed explanation, SO-1: Use geostrategic position to be the main energy hub in the East Mediterranean Region, this strategy uses Turkey's internal strengths (geostrategic position) in order to take advantage of external opportunities, such as joining the new formations in energy transportations or security. WO-1 strategy depicts improving internal weaknesses by taking advantage of external opportunities. WO-1 strategy presumes the support of Europe. The other strategy is ST-1 which uses strengths to avoid or reduce the impact of external threats. For Turkey, trying to build up regional economic unions and decrease the instability in the East Mediterranean Region brings an option for the energy strategies. Lastly, we use WT strategies to reduce the internal weaknesses and avoiding environmental threats.

After determination the strategies in other words the alternatives, interactions between sub-criteria are needed to be determined. It means that some criteria can affect each other's priorities. Table 7 gives the interactions between sub-criteria. For instance, the criterion "W1: A failure to achieve global competitiveness" is affected by W-5: Lack of energy transportation infrastructure and T-5: Environmental threat and cost of the energy transportation.

All relationships between the sub-criteria are illustrated in Figure 5. In Figure 5, onesided arrow shows the criterion which is influenced by the other criteria while a two-sided arrow between two criteria shows that two criteria affect each other.

The ANP method allows for complex interrelationships among attributes and uses pairwise comparisons to determine criteria weights. Main criteria under the goal are paired and the following question: "which criterion is more important than the other?" is asked to the expert team. The experts select one criterion and then determine the degree according to the scale in Table 5. At the last step, a super matrix which is actually a partitioned matrix is formed and criteria weights are calculated by getting limit matrix. The software "Super Decisions" directs users to solicit evaluations, then applies these steps automatically and makes the process easier for users. This is the reason that we, the author(s) of this paper, prefer to use the software in our study. After the network structure is built, the software directs the user to the assessment and comparisons for each criterion are applied. The pairwise comparison matrix for the sub-criteria in the cluster named system quality is shown in Figure 6. The blue number and arrow show that the criterion in the row is more important than the criterion in the column. The red ones show the other situation. For instance, WT-1 is 1.6 
Table 6. SWOT matrix of natural gas for Turkey

\begin{tabular}{|c|c|c|}
\hline External Factors & \begin{tabular}{l}
\multicolumn{1}{c}{ Strengths } \\
1. An energy hub, not simply \\
energy corridors (S-1). \\
2. Strong military power \\
(including navy power) to \\
secure the energy corridors \\
(S-2). \\
3. A role of stable country \\
in the South Mediterranean \\
Region (S-3). \\
4. Dedicated and strong \\
government (S-4). \\
5. Implement plans to improve \\
energy transportation (S-5).
\end{tabular} & $\begin{array}{l}\quad \text { Weaknesses } \\
\text { 1. A failure to achieve global } \\
\text { competitiveness (W-1). } \\
\text { 2. An increasing population } \\
\text { and energy need (W-2). } \\
\text { 3. Over urbanization (W-3). } \\
\text { 4. Economy, fast developing } \\
\text { but not one of the main } \\
\text { decision maker (W-4). } \\
\text { 5. Lack of energy } \\
\text { transportation infrastructure } \\
(\text { W-5). }\end{array}$ \\
\hline $\begin{array}{l}\text { Opportunities } \\
\text { 1. Proximity to Russia and Central } \\
\text { Asia Energy Providers (As an } \\
\text { alternative energy suppliers) (O-1). } \\
\text { 2. Proximity to Europe, one of the } \\
\text { biggest energy markets (O-2). } \\
\text { 3. Membership to the most } \\
\text { important international } \\
\text { organizations (NATO, OPEC, etc.) } \\
\text { (O-3). } \\
\text { 4. Political support of the } \\
\text { international community for the } \\
\text { projects (O-4). } \\
\text { 5. The shortest distances for the } \\
\text { energy transportation to Europe } \\
\text { (O-5). }\end{array}$ & $\begin{array}{l}\text { SO Strategies } \\
\text { 1. Use geostrategic position to } \\
\text { be the main energy hub in the } \\
\text { East Mediterranean Region } \\
\text { (SO-1). } \\
\text { 2. Use political support from } \\
\text { international community for } \\
\text { being the main energy hub in } \\
\text { the East Mediterranean Region } \\
\text { (SO-2). }\end{array}$ & $\begin{array}{l}\quad \text { WO Strategies } \\
\text { 3. Compensate the lack } \\
\text { of energy transportation } \\
\text { infrastructure by the support } \\
\text { of Europe (WO-1). } \\
\text { 4. Adopt new rules for } \\
\text { overcoming the financial } \\
\text { difficulties on the strength } \\
\text { of geostrategic position } \\
\text { (WO-2). }\end{array}$ \\
\hline $\begin{array}{l}\text { Threats } \\
\text { 1. Highly dependent to external } \\
\text { energy suppliers (T-1). } \\
\text { 2. Unstable neighbors (T-2). } \\
\text { 3. Poor relations with Israel and } \\
\text { Greek Cypriot Administration of } \\
\text { Southern Cyprus (T-3). } \\
\text { 4. The latest incidents in Middle } \\
\text { East Countries (T-4). } \\
\text { 5. Environmental threat and cost of } \\
\text { the energy transportation (T-5). }\end{array}$ & $\begin{array}{l}\quad \text { ST Strategies } \\
\text { 5. Try to build up regional } \\
\text { economic unions and decrease } \\
\text { the instability in the East } \\
\text { Mediterranean Region (ST-1). } \\
\text { 6. Have continuous and } \\
\text { consistent plans to improve } \\
\text { energy transportation (ST-2). }\end{array}$ & $\begin{array}{l}\quad \text { WT Strategies } \\
\text { 7. Have new alliances to be } \\
\text { new global actor in energy } \\
\text { issue (WT-1). }\end{array}$ \\
\hline
\end{tabular}

Table 7. SWOT matrix and connections

\begin{tabular}{|c|c|}
\hline SWOT Matrix & Connections \\
\hline $\begin{array}{l}\text { Strengths } \\
\text { 1. An energy hub, not simply energy corridors (S-1) } \\
\text { 2. Strong military power (including navy power) to secure } \\
\text { the energy corridors (S-2) } \\
\text { 3. A role of stable country in the South Mediterranean } \\
\text { Region (S-3) } \\
\text { 4. Dedicated and strong government (S-4) } \\
\text { 5. Implement plans to improve energy transportation (S-5) }\end{array}$ & $\begin{array}{l}\text { S-5, W-5, O-1, O-2, O-5, T-2 } \\
\text { S-3, S-4, T-2, T-3, T-4 } \\
\text { S-2, S-4, O-1, O-2, T-2, T-3, T-4 } \\
\text { S-2, S-3, S-5, O-3, T-2,T-3 } \\
\text { S-1, S-4, W-3, W-4- W-5, O-1, O-2, } \\
\text { O-3, O-5, T-1, T-5 }\end{array}$ \\
\hline
\end{tabular}


End of Table 7

\begin{tabular}{|c|c|}
\hline SWOT Matrix & Connections \\
\hline $\begin{array}{l}\text { Weaknesses } \\
\text { 1. A failure to achieve global competitiveness (W-1) } \\
\text { 2. An increasing population and energy need (W-2) } \\
\text { 3. Over urbanization (W-3) } \\
\text { 4. Economy, fast developing but not one of the main } \\
\text { decision maker (W-4) } \\
\text { 5. Lack of energy transportation infrastructure (W-5) }\end{array}$ & $\begin{array}{l}\text { W-5, T-5 } \\
\text { W-3, W-4, S-5, T-1 } \\
\text { W-2, T-1, T-2, T-4 } \\
\text { S-3, S-4, S-5, O-2 } \\
\text { S5, W1, W4, T5 }\end{array}$ \\
\hline $\begin{array}{l}\text { Opportunities } \\
\text { 1. Proximity to Russia and Central Asia Energy Providers } \\
\text { (O-1) } \\
\text { 2. Proximity to Europe, one of the biggest energy markets } \\
\text { (O-2) } \\
\text { 3. Membership to the most important international } \\
\text { organizations (NATO, OPEC) (O-3) } \\
\text { 4. Political support of the international community for the } \\
\text { projects (O-4) } \\
\text { 5. The shortest distances for the energy transportation to } \\
\text { Europe (O-5) }\end{array}$ & $\begin{array}{l}\text { O-2, O-3, O-5 } \\
\text { O-1, O-3, O-4, O-5, S-3, S-4 } \\
\text { S2, S3, S-4, O-4, T-2 } \\
\text { S2, S-3, S-4, S-5, O-2, O-3, O-5 } \\
\text { O-1, O-2, T-3 }\end{array}$ \\
\hline $\begin{array}{l}\text { Threats } \\
\text { 1. Highly dependent to external energy suppliers (T-1) } \\
\text { 2. Unstable neighbors (T-2) } \\
\text { 3. Poor relations with Israel and Greek Cypriot } \\
\text { Administration of Southern Cyprus (T-3) } \\
\text { 4. The latest incidents in Middle East Countries (T-4) } \\
\text { 5. Environmental threat and cost of the energy } \\
\text { transportation (T-5) }\end{array}$ & $\begin{array}{l}\text { S-1, S-5, W-2, W-3, O-1 } \\
\text { S-2, S-3, S-4, O-3, T-4 } \\
\text { S-2, S-3, T-2, T-4 } \\
\text { S-2, S-3, T-2, T-3 } \\
\text { S-1, S-3, W-5, O-2, O-5 }\end{array}$ \\
\hline
\end{tabular}



Fig. 5. The network structure of the criteria evaluation 


\begin{tabular}{|c|c|c|c|c|c|c|c|c|c|}
\hline 1. Choose & \multicolumn{7}{|c|}{ 2. Node comparisons with respect to $S 1$} & \multicolumn{2}{|c|}{+3 . Results } \\
\hline Node Cluster & \multicolumn{7}{|c|}{\begin{tabular}{|l|l|l|} 
Graphical & Verbal & Mattix Questionnaire \\
\end{tabular}} & Normal - & Hybrid - \\
\hline Choose Node $\triangle 1$ & Comparisons & wit "S1" node & e in "Alternati & ives" cluster & & & & \multicolumn{2}{|c|}{ Inconsistency: 0.00421} \\
\hline-1 & WT- 1 is $1.6 \mathrm{ti}$ & mes mor & & & & & & S0-1 & 0.19167 \\
\hline \multirow{2}{*}{ Cluster. Strengths } & Inconsistency & 50-2 & ST-1 $\sim$ & ST-2 $~ \sim$ & wo-1 $\sim$ & W0-2 $\sim$ & WT-1 $\sim$ & \begin{tabular}{|l|} 
SO-2 \\
\end{tabular} & 0.16351 \\
\hline & $50-1 \quad \sim$ & \multirow{8}{*}{$\leftarrow 1.0632$} & $\leftarrow 1.2537$ & $\leftarrow 2.2923$ & $\leftarrow 1.5555$ & $\leftarrow 1.68$ & $\leftarrow 1.05$ & ST-1 & 0.13867 \\
\hline Choose Cluster $\Delta \nabla$ & $50-2 \sim$ & & \multirow[t]{5}{*}{$\leftarrow 1.1791$} & $\leftarrow 1.2153$ & $\leftarrow 1.4629$ & $\leftarrow 1.58$ & $\uparrow 1.0126$ & $\frac{\mathrm{ST}-2}{\mathrm{~W} 0-1}$ & 0.12533 \\
\hline Alternatives & ST-1 $\sim$ & & & \multirow[t]{4}{*}{$\leftarrow 1.0307$} & $\leftarrow 1.2407$ & $\leftarrow 1.34$ & \begin{tabular}{|l|l|}
$\uparrow$ & 1.1940 \\
\end{tabular} & W0-2 & 0.10348 \\
\hline & ST-2 & & & & \multirow[t]{3}{*}{$\leftarrow 1.2037$} & $\leftarrow 1.3$ & $\longdiv { \uparrow 1 . 2 3 0 7 }$ & \multirow[t]{3}{*}{ WT-1 } & \multirow[t]{3}{*}{0.16558} \\
\hline & W0-1 & & & & & $\leftarrow 1.08$ & $\uparrow 1.4814$ & & \\
\hline & W0-2 & & & & & & \begin{tabular}{|l|l|}
$\uparrow$ & 1.6 \\
\end{tabular} & & \\
\hline & & & & & & & & ? & $\begin{array}{l}\text { eted } \\
\text { rison }\end{array}$ \\
\hline Restore | & & & & Copy to clipboard & & & & & board | \\
\hline
\end{tabular}

Fig. 6. The pairwise comparison matrix of alternatives based on S1 criterion

times more important than WO-2. The ANP method requires the inconsistency ratio (CR) to be smaller than 0.1 ; this that means the user makes the evaluations consistently. CRs of the all pairwise comparison matrixes in the model are smaller than 0.1. All other pairwise comparison matrixes are done in similar way. Evaluations are then completed and the criteria priorities are calculated as given in Table 8.

Table 8 . The criteria priorities obtained by ANP

\begin{tabular}{|c|c|}
\hline SWOT Matrix & Priorities \\
\hline $\begin{array}{l}\text { Strengths } \\
\text { 1. An energy hub, not simply energy corridors (S-1) } \\
\text { 2. Strong military power (including navy power) to secure the energy corridors (S-2) } \\
\text { 3. A role of stable country in the South Mediterranean Region (S-3) } \\
\text { 4. Dedicated and strong government (S-4) } \\
\text { 5. Implement plans to improve energy transportation (S-5) }\end{array}$ & $\begin{array}{l}0.00762 \\
0.11761 \\
0.08854 \\
0.11580 \\
0.04165\end{array}$ \\
\hline $\begin{array}{l}\text { Weaknesses } \\
\text { 1. A failure to achieve global competitiveness }(\mathrm{W}-1) \\
\text { 2. An increasing population and energy need (W-2) } \\
\text { 3. Over urbanization (W-3) } \\
\text { 4. Economy, fast developing but not one of the main decision maker (W-4) } \\
\text { 5. Lack of energy transportation infrastructure (W-5) }\end{array}$ & $\begin{array}{l}0.00279 \\
0.00469 \\
0.00868 \\
0.00386 \\
0.01193\end{array}$ \\
\hline $\begin{array}{l}\text { Opportunities } \\
\text { 1. Proximity to Russia and Central Asia Energy Providers (O-1) } \\
\text { 2. Proximity to Europe, one of the biggest energy markets (O-2) } \\
\text { 3. Membership to the most important international organizations (NATO, OPEC, etc.) (O-3) } \\
\text { 4. Political support of the international community for the projects (O-4) } \\
\text { 5. The shortest distances for the energy transportation to Europe (O-5) }\end{array}$ & $\begin{array}{l}0.01948 \\
0.05499 \\
0.11428 \\
0.04429 \\
0.02886\end{array}$ \\
\hline $\begin{array}{l}\text { Threats } \\
\text { 1. Highly dependent to external energy suppliers (T-1) } \\
\text { 2. Unstable neighbors (T-2) } \\
\text { 3. Poor relations with Israel and Greek Cypriot Administration of Southern Cyprus (T-3) } \\
\text { 4. The latest incidents in Middle East Countries (T-4) } \\
\text { 5. Environmental threat and cost of the energy transportation (T-5) }\end{array}$ & $\begin{array}{l}0.00542 \\
0.15359 \\
0.04857 \\
0.11309 \\
0.01426\end{array}$ \\
\hline
\end{tabular}


Then the relative weights obtained from the analysis of paired comparisons tables for ranking the alternatives are calculated. Obtained weights of seven alternatives are given in Table 9.

Based on the achieved weight in Table 9, ST-1 strategy "Try to build up regional economic unions and decrease the instability in the East Mediterranean Region" is the highest weight. On the contrary, strategy WO-1 "Compensate the lack of energy transportation infrastructure by the support of Europe" is the worst policy.

Table 9. The priorities of alternatives obtained by ANP

\begin{tabular}{|c|c|c|}
\hline & Alternative strategies & Priorities \\
\hline \multirow[t]{2}{*}{$\mathrm{SO}$} & $\begin{array}{l}\text { Use geostrategic position to be the main energy hub in the East Mediterranean } \\
\text { Region (SO-1) }\end{array}$ & 0.158734 \\
\hline & $\begin{array}{l}\text { Use political support from international community for being the main energy } \\
\text { hub in the East Mediterranean Region (SO-2) }\end{array}$ & 0.164214 \\
\hline \multirow[t]{2}{*}{ ST } & $\begin{array}{l}\text { Try to build up regional economic unions and decrease the instability in the East } \\
\text { Mediterranean Region (ST-1) }\end{array}$ & 0.176513 \\
\hline & Have continuous and consistent plans to improve energy transportation (ST-2) & 0.142502 \\
\hline \multirow[t]{2}{*}{ WO } & $\begin{array}{l}\text { Compensate the lack of energy transportation infrastructure by the support of } \\
\text { Europe (WO-1) }\end{array}$ & 0.095865 \\
\hline & $\begin{array}{l}\text { Adopt new rules for overcoming the financial difficulties on the strength of } \\
\text { geostrategic position (WO-2) }\end{array}$ & 0.121115 \\
\hline WT & Have new alliances to be new global actor in energy issue (WT-1) & 0.141046 \\
\hline
\end{tabular}

\subsection{Application of different solution approaches}

In addition to current solution approach (SWOT-ANP), extra methods are applied to evaluate natural gas strategies of Turkey in this section. Table 10 presents the applied integrated solution approaches with their definition. Pairwise matrixes of ANP are also used for AHP. For simplicity sake, the calculation steps of the TOPSIS (Technique for Order Preference by Similarity to Ideal Solution) method are not presented. However, they are available upon request.

While Table 11 gives the priorities of criteria obtained by AHP, ranking weights of strategies obtained by TOPSIS are given in Table 12 .

Table 10. Applied solution approaches

\begin{tabular}{|l|l|}
\hline \multicolumn{1}{|c|}{ Abbreviation } & \multicolumn{1}{c|}{ Definition } \\
\hline Method1 (Current solution) & Strategies by SWOT, weighted and ranked by ANP \\
\hline Method2 & Strategies by SWOT, weighted and ranked by AHP \\
\hline Method3 & Strategies by SWOT, weighted by ANP, ranked by TOPSIS \\
\hline Method4 & Strategies by SWOT, weighted by AHP, ranked by TOPSIS \\
\hline Method5 & Strategies by SWOT, weighted equally, ranked by TOPSIS \\
\hline
\end{tabular}


Table 11. The criteria priorities obtained by AHP

\begin{tabular}{|c|c|c|c|c|c|c|c|}
\hline Strengths & Priorities & Weaknesses & Priorities & Opportunities & Priorities & Threats & Priorities \\
\hline S-1 & 0.00518 & W-1 & 0.00112 & O- 1 & 0.03919 & T-1 & 0.00470 \\
\hline S-2 & 0.11478 & W-2 & 0.00246 & O-2 & 0.05063 & T-2 & 0.13712 \\
\hline S-3 & 0.13211 & W-3 & 0.00345 & O-3 & 0.10810 & T-3 & 0.08801 \\
\hline S-4 & 0.10057 & W-4 & 0.00374 & O-4 & 0.04429 & T-4 & 0.10362 \\
\hline S-5 & 0.02312 & W-5 & 0.00633 & O-5 & 0.02542 & T-5 & 0.00605 \\
\hline
\end{tabular}

Table 12. Ranking obtained by TOPSIS

\begin{tabular}{|c|c|c|c|c|c|c|c|c|c|}
\hline \multirow[b]{2}{*}{ Strategies } & \multicolumn{3}{|c|}{ Method 3} & \multicolumn{3}{|c|}{ Method 4} & \multicolumn{3}{|c|}{ Method 5} \\
\hline & $S_{i}^{*}$ & $S_{i}^{-}$ & $C_{i}$ & $S_{i}^{*}$ & $S_{i}^{-}$ & $C_{i}$ & $S_{i}^{*}$ & $S_{i}^{-}$ & $C_{i}$ \\
\hline SO-1 & 0.02311 & 0.02819 & 0.54953 & 0.02236 & 0.02749 & 0.55143 & 0.01854 & 0.01791 & 0.49136 \\
\hline SO-2 & 0.02150 & 0.02991 & 0.58188 & 0.02058 & 0.02943 & 0.58846 & 0.01758 & 0.01837 & 0.51097 \\
\hline ST-1 & 0.01381 & 0.03764 & 0.73160 & 0.01378 & 0.03724 & 0.72995 & 0.01758 & 0.01893 & 0.51849 \\
\hline ST-2 & 0.03031 & 0.02531 & 0.45509 & 0.03199 & 0.02232 & 0.41096 & 0.01673 & 0.02259 & 0.57457 \\
\hline WO-1 & 0.04078 & 0.00630 & 0.13376 & 0.04019 & 0.00575 & 0.12525 & 0.02496 & 0.01227 & 0.32963 \\
\hline WO-2 & 0.03574 & 0.01914 & 0.34876 & 0.03474 & 0.01824 & 0.34421 & 0.02082 & 0.01590 & 0.43302 \\
\hline WT-1 & 0.02965 & 0.02360 & 0.44319 & 0.02788 & 0.02407 & 0.46333 & 0.02096 & 0.01701 & 0.44792 \\
\hline
\end{tabular}

Figure 7 illustrates the final rankings of strategies according to each applied method by using the data in Tables 11 and 12. Strategies' ranks calculated with the method 5 are a little different depending on equal criteria weights. It is the fact that criteria weights differ according to countries, the time on which strategies are evaluated. As a result, ranks calculated with the first four methods are more logical than the last one.

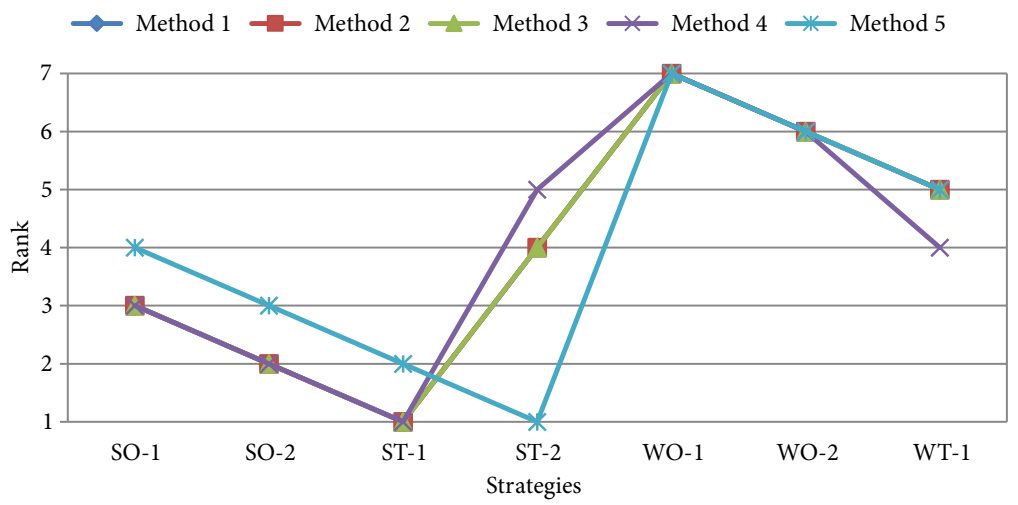

Fig. 7. Comparison of different solution approaches 


\subsection{Discussion}

A SWOT ANP hybrid method is performed to evaluate and rank the natural gas strategies of Turkey based on the conditions of Eastern Mediterranean Region. The main reason of using ANP is to consider possible dependency among factors, sub-factors and alternatives (strategies). Different solution approaches such as AHP and TOPSIS are applied to see the changes on ranking. It is obvious that consideration of the different methods causes remarkable changes in ranking alternatives especially about high important alternatives. The overall computed priorities for alternative strategies shows that SO-2 and ST-1 strategies are the best strategies. Using political support from international community for being the main energy hub in the East Mediterranean Region and trying to build up regional economic unions and decrease the instability in the East Mediterranean Region is determined as the best strategies for natural gas policy of Turkey.

These strategies could be the best strategies when you consider the all alternatives in the beginning without using quantitative methods. We showed the applicability of hybrid MCDM methods over the energy strategies of Turkey. We also tried to demonstrate that the strategies should be decided by based on mathematical approaches, not conventional decision making methods. For that reason, we applied hybrid MCDM methods to get solid results from the strategies derived by the experts.

The results show that potential of economic unions in the region is the most important opportunity for Turkey's natural gas strategies. Also if Turkey can get a political support from the rest 9 East Mediterranean Region countries to be an energy hub in the region, she would take the opportunity to increase natural gas share.

\section{Conclusions}

Energy is needed for everything; to power homes, drive cars, to use technology and even to feed and clothe human beings. Energy underpins modern life and that's why it's the issue of our time. Natural gas is the most important form of energy because it is clean, abundant, reliable and versatile. Thus it will play a key role in ensuring people's energy demands in the future. Like all the resources in nature, sharing natural gas resources can cause chaos over the energy regions.

The conflicts and disputes in an energy region are forcing the countries to implement suitable strategic energy policies based on scientific methods. The decision context is related not only with the energy supply/demand, but also with the political, environmental, administrative, legal and market issues. Therefore, using a scientific and efficient method to select the best strategies is inevitable. In this study, an integrated SWOT-ANP approach is applied to evaluate natural gas policies of Turkey for the East Mediterranean Region. The strategies are determined via SWOT analysis including four criteria, 20 sub-criteria and seven strategies. The ANP approach that considers the dependency between factors is applied to prioritize these strategies. Different solution approaches such as AHP and TOPSIS are applied to see the changes on ranking. Consideration of different methods causes remarkable changes in ranking alternatives. Results show that, SO-2 and ST-1 strategies are determined as the best 
strategies. That means; "Using political support from international community for being the main energy hub in the East Mediterranean Region" and "Trying to build up regional economic unions and decreasing the instability in the East Mediterranean Region" are the best strategies for natural gas policies of Turkey. According to obtained results, it is shown that proposed integrated approach is an effective and applicable tool for energy policy making considering the real life conditions. Although one can think that scientific techniques can be useless on political or strategic decisions, scientific methods can help decision makers if the problem is revealed properly.

Future research can be performed based on dependency effects between SWOT sub-factors and strategies. In addition to applying this model to the different energy resource types, different MCDM techniques or fuzzy methods can be implemented on the same problem.

\section{Acknowledgements}

The authors express sincere appreciation to the editor and anonymous reviewers for their efforts to improve the quality of this paper. The authors would also like to thank two experts from Ministry of Energy and Natural Resources for their valuable contributions. Third author was supported by the BAGEP Award of the Science Academy in Turkey.

\section{References}

Adam, F.; Humphreys, P. 2008. Encyclopedia of decision making and decision support technologies. New York, NY: Information Science Reference Press. https://doi.org/10.4018/978-1-59904-843-7

AEO. 2013. Annual energy outlook 2013 with projections to 2040 [online], [cited 16 May 2016]. U.S. Energy Information Administration. Available from Internet: http://www.eia.gov/forecasts/aeo/ pdf/0383(2013).pdf

Arabzad, S. M.; Ghorbani, M.; Razmi, J.; Shirouyehzad, H. 2015. Employing fuzzy TOPSIS and SWOT for supplier selection and order allocation problem, The International Journal of Advanced Manufacturing Technology 76: 803-818. https://doi.org/10.1007/s00170-014-6288-3

Aruldoss, M.; Lakshmi, M.; Venkatesan, V. P. 2013. A survey on multi criteria decision making methods and its applications, American Journal of Information Systems 1(1): 31-43.

Azimi, R.; Chamzini, A. Y.; Fooladgar, M. M.; Basiri, M. H. 2011b. Evaluating the strategies of the Iranian mining sector using an integrated model, International Journal of Management Science and Engineering Management 6(6): 459-466.

Azimi, R.; Chamzini, A. Y.; Fouladgar, M. M.; Zavadskas, E. K.; Basiri, M. H. 2011a. Ranking the strategies of mining sector through ANP and TOPSIS in a SSOT framework, Journal of Business Economics and Management 12(4): 670-689. https://doi.org/10.3846/16111699.2011.626552

Babaesmailli, M.; Arbabshirani, B.; Golmah, V. 2012. Integrating analytical network process and fuzzy logic to prioritize the strategies - a case study for tile manufacturing firm, Expert Systems with Applications 39: 925-935. https://doi.org/10.1016/j.eswa.2011.07.090

Bas, E. 2013. The integrated framework for analysis of electricity supply chain using an integrated SWOT-fuzzy TOPSIS methodology combined with AHP: the case of Turkey, Electrical Power and Energy Systems 44: 897-907. https://doi.org/10.1016/j.ijepes.2012.08.045

Chaghooshi, A. J.; Fathi, M. R.; Omidian, A.; Zarchi, M. K. 2011. Integration of FPM, fuzzy AHP and ANP Methods in formulation of software industry strategy, Australian Journal of Basic and Applied Sciences 5(9): 1232-1247. 
Chang, H. H.; Huang, W. C. 2006. Application of a quantification SWOT analytical method, Mathematical and Computer Modelling 43(1-2): 158-169. https://doi.org/10.1016/j.mcm.2005.08.016

David, F. R. 2007. Strategic management concepts and cases. $11^{\text {th }}$ ed. New York, NY: Prentice Hall Press.

ECA. 2015. Improving the security of energy supply by developing the internal energy market: more efforts needed [online], [cited 16 May 2016]. Available from Internet: http://www.eca.europa.eu/Lists/ECA Documents/SR15_16/SR_ENERGY_SECURITY-EN.pdf

Gavade, R. K. 2014. Multi-criteria decision making: an overview of different selection problems and methods, International Journal of Computer Science and Information Technologies 5(4): 5643-5646.

Groselj, P.; Stirn, L. Z. 2015. The environmental management problem of Pohorje, Slovenia: a new group approach within ANP-SWOT framework, Journal of Environmental Management 161: 106-112. https://doi.org/10.1016/j.jenvman.2015.06.038

Harrison, J. P. 2010. Essentials of strategic planning in healthcare. New York, NY: Health Administration Press.

Hashemi, N. F.; Mazdeh, M. M.; Razeghi, A.; Rahimian, A. 2011. Formulating and choosing strategies using SWOT analysis and QSPM Matrix: a case study of Hamadan Glass Company, in $41^{\text {st }}$ International Conference on Computers \& Industrial Engineering, 23-26 October 2011, Los Angeles, U.S.

Houben, G.; Lenie, K.; Vanhoof, K. 1999. A knowledge-based SWOT-analysis system as an instrument for strategic planning in small and medium sized enterprises, Decision Support Systems 26(2): 125-135. https://doi.org/10.1016/S0167-9236(99)00024-X

Jeyaraj, K. L.; Muralidharan, C.; Senthilvelan, T.; Deshmukh, S. G. 2012. Application of SWOT and principal component analysis in a Textile Company - a case study, International Journal of Engineering Research and Development 1(9): 46-54.

Kajanus, M.; Kangas, J.; Kurttila, M. 2004. The use of value focused thinking and the A'WOT hybrid method in tourism management, Tourism Management 25(4): 499-506.

https://doi.org/10.1016/S0261-5177(03)00120-1

Kangas, J.; Kurtila, M.; Kajanus, M.; Kangas, A. 2003. Evaluating the management strategies of a forestland estate-the S-O-S approach, Journal of Environmental Management 69(4): 349-358. https://doi.org/10.1016/j.jenvman.2003.09.010

Karppi, I.; Kokkononen, M.; Lähteenmäki-Smith, K. 2001. SWOT analysis as a basis for regional strategies. Nordregio Working Paper. Stockholm: Nordregio.

Koehler, M. 2012. Gas discoveries in the Eastern Mediterranean: implications for the European Union [online], [cited 16 May 2016]. Eastern Mediterranean Energy Project Policy Brief. Available from Internet: http://www.gmfus.org/publications/gas-discoveries-eastern-mediterranean-implicationseuropean-union

Lee, Y. H. 2015. Navigating SWOT-FANP with GSM method to prioritize the strategic location, Technological and Economic Development of Economy 21(1): 140-163. https://doi.org/10.3846/20294913.2015.1004566

Lu, W. S. 2010. An improved SWOT approach for conducting strategic planning in the construction industry, Journal of Construction Engineering and Management 136(12): 1317-1328. https://doi.org/10.1061/(ASCE)CO.1943-7862.0000240

OME. 2011. A Mediterranean energy outlook [online], [cited 16 May 2016]. Observatoire Méditerranéen de l'Energie. Available from Internet: http://www.kyotoclub.org/docs/rimini111111_KeyEnergy_Vigotti.pdf

Reinsberger, K.; Brudermann, T.; Posch, A. 2015. The role of photovoltaics in energy transition - assessing the prospects for a regime shift, GAIA - Ecological Perspectives for Science and Society 24(1): 41-47.

Saaty, T. L. 1980. The analytic hierarchy process. New York, NY: McGraw-Hill. 
Saaty, T. L. 1994. How to make a decision: the analytic hierarchy process, Interfaces 24(6): 19-43. https://doi.org/10.1287/inte.24.6.19

Saaty, T. L. 2005. Theory and applications of the analytic network process. Pittsburgh, RWS Publications.

Saaty, T. L.; Özdemir, M. S. 2005. The encyclion: a dictionary of decisions with dependence and feedback based on the analytic network process. New York, NY: RWS Publications.

Saaty, T. L.; Vargas, L. G. 2006. Decision making with the analytic network process: economic, political, social and technological applications with benefits, opportunities, costs and risks. New York, NY: Springer.

Saaty, T. L.; Vargas, L. G. 1998. Diagnosis with dependent symptoms: Bayes theorem and the analytic hierarchy process, Operations Research 46(4): 491-502. https://doi.org/10.1287/opre.46.4.491

Sevkli, M.; Oztekin, A.; Uysal, O.; Torlak, G.; Turkyilmaz, A.; Delen, D. 2012. Development of a fuzzy ANP based SWOT analysis for the airline industry in Turkey, Expert Systems with Applications 39(1): 14-24. https://doi.org/10.1016/j.eswa.2011.06.047

Shaffer, B. 2012. Energy resources and markets in the Eastern Mediterranean Region [online], [cited 16 May 2016]. Eastern Mediterranean Energy Project Policy Brief. Available from Internet: http:// www.gmfus.org/archives/energy-resources-and-marketsin-the-eastern mediterranean-region

Shahabi, R. S.; Basiri, M. H.; Kahag, M. R.; Zonouzi, S. A. 2014. An ANP-SWOT approach for interdependency analysis and prioritizing the Iran's steel scrap industry strategies, Resources Policy 42: 18-26. https://doi.org/10.1016/j.resourpol.2014.07.001

Tavana, M.; Pirdashti, M.; Kennedy, D. T.; Belaud, J. P.; Behzadian, M. 2012. A hybrid Delphi-SWOT paradigm for oil and gas pipeline strategic planning in Caspian Sea basin, Energy Policy 40: 345360. https://doi.org/10.1016/j.enpol.2011.10.020

Tavana, M.; Pirdashti, M.; Kennedy, D. T.; Belaud, J. P.; Behzadian, M. 2013. A PROMETHEE-GDSS for oil and gas pipeline planning in the Caspian Sea basin, Energy Economics 36: 716-728. https://doi.org/10.1016/j.eneco.2012.11.023

Vanek, M.; Mikolas, M.; Zvakova, K. 2012. Evaluation methods of SWOT analysis, GeoScience Engineering 58(2): 23-31. https://doi.org/10.2478/gse-2014-0036

Weihrich, H. 1982. The TOWS matrix: a tool for situational analysis, Long Range Planning 15(2): 54-66. https://doi.org/10.1016/0024-6301(82)90120-0

WEO. 2014. World energy outlook 2014 report [online], [cited 16 May 2016]. International Energy Agency. Available from Internet: https://www.iea.org/publications/freepublications/publication/ WEO_2014_ES_English_WEB.pdf

Wheelen, T. L.; Hunger, J. D. 1995. Strategic management and business policy. $5^{\text {th }}$ ed. New Jersey, NJ: Prentice Hall Press.

Yüksel, İ.; Dağdeviren, M. 2007. Using the analytic network process (ANP) in a SWOT analysis - a case study for a textile firm, Information Sciences 177(16): 3364-3382. https://doi.org/10.1016/j.ins.2007.01.001

Zheng, L.; Liu, H. 2013. Evaluating multifunctional agriculture in Dalishu, China: a combined application of SWOT analysis and the analytic network process method, Outlook on Agriculture 42(2): 103-108. https://doi.org/10.5367/oa.2013.0128

Zhou, L.; Chen, Y. 2014. Exploring the potential of community-based grassland management in Yanchi County of Ningxia Hui Autonomous Region, China: an application of the SWOT-AHP method, Environmental Earth Sciences 72(6): 1811-1820. https://doi.org/10.1007/s12665-014-3090-3 